\title{
Efficacy and safety of mesenchymal stromal cells in preclinical models of acute lung injury: a systematic review protocol
}

Manoj M Lalu ${ }^{1,5}$, David Moher ${ }^{5,7}$, John Marshall ${ }^{6}$, Dean Fergusson ${ }^{5}$, Shirley HJ Mei ${ }^{3}$, Malcolm Macleod $^{8}$, Gilly Griffin ${ }^{10}$, Alexis F Turgeon ${ }^{11,12}$, Michael Rudnicki ${ }^{3}$, Jason Fishman ${ }^{14}$, Marc T Avey ${ }^{5}$, Becky Skidmore ${ }^{15}$, Jeremy M Grimshaw ${ }^{5,9}$, Duncan J Stewart ${ }^{3,4}$, Kavita Singh ${ }^{5}$, Lauralyn McIntyre ${ }^{2,5,13^{*}}$ and For the Canadian Critical Care Translational Biology Group

\begin{abstract}
Background: Acute respiratory distress syndrome (ARDS) in humans is caused by an unchecked proinflammatory response that results in diffuse and severe lung injury, and it is associated with a mortality rate of 35 to $45 \%$. Mesenchymal stromal cells (MSCs; 'adult stem cells') could represent a promising new therapy for this syndrome, since preclinical evidence suggests that MSCs may ameliorate lung injury. Prior to a human clinical trial, our aim is to conduct a systematic review to compare the efficacy and safety of MSC therapy versus controls in preclinical models of acute lung injury that mimic some aspects of the human ARDS.

Methods/Design: We will include comparative preclinical studies (randomized and non-randomized) of acute lung injury in which MSCs were administered and outcomes compared to animals given a vehicle control. The primary outcome will be death. Secondary outcomes will include the four key features of preclinical acute lung injury as defined by the American Thoracic Society consensus conference (histologic evidence of lung injury, altered alveolar capillary barrier, lung inflammatory response, and physiological dysfunction) and pathogen clearance for acute lung injury models that are caused by infection. Electronic searches of MEDLINE, Embase, BIOSIS Previews, and Web of Science will be constructed and reviewed by the Peer Review of Electronic Search Strategies (PRESS) process. Search results will be screened independently and in duplicate. Data from eligible studies will be extracted, pooled, and analyzed using random effects models. Risk of bias will be assessed using the Cochrane risk of bias tool, and individual study reporting will be assessed according to the Animal Research: Reporting of In Vivo Experiments (ARRIVE) guidelines.
\end{abstract}

Discussion: The results of this systematic review will comprehensively summarize the safety and efficacy of MSC therapy in preclinical models of acute lung injury. Our results will help translational scientists and clinical trialists to determine whether sufficient evidence exists to perform a human clinical trial. These results may also guide future acute lung injury preclinical and clinical research.

Keywords: Mesenchymal stromal cells, Mesenchymal stem cells, Acute lung injury, Acute respiratory distress syndrome, Preclinical, Systematic review protocol

\footnotetext{
* Correspondence: Imcintyre@ottawahospital.on.ca

${ }^{2}$ Department of Medicine (Division of Critical Care), University of Ottawa,

Ottawa, ON, Canada

${ }^{5}$ Clinical Epidemiology Program, The Ottawa Hospital Research Institute,

Ottawa, ON, Canada

Full list of author information is available at the end of the article
}

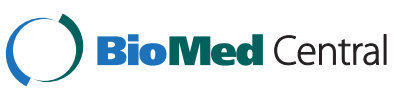

(c) 2014 Lalu et al.; licensee BioMed Central Ltd. This is an Open Access article distributed under the terms of the Creative Commons Attribution License (http://creativecommons.org/licenses/by/2.0), which permits unrestricted use, distribution, and reproduction in any medium, provided the original work is properly credited. The Creative Commons Public Domain Dedication waiver (http://creativecommons.org/publicdomain/zero/1.0/) applies to the data made available in this article, unless otherwise stated. 


\section{Background}

Acute respiratory distress syndrome (ARDS) is a devastating clinical condition caused by an acute, diffuse, and severe lung injury that requires management in the intensive care unit. It is characterized by unchecked inflammation that leads to severe hypoxemia, pulmonary alveolar and capillary membrane leakage, and progressive respiratory failure [1,2]. Approximately 200,000 new cases are identified in the United States each year [3] and it is a leading cause of death with mortality rates of approximately 35 to $45 \%$ [4].Significant long-term sequelae for survivors include physical, psychological, and emotional dysfunction that results in only half of previously healthy individuals returning to employment at one year after their illness $[3,5,6]$. The ARDS also carries a significant economic burden, as it has the highest cost per case of any acute care condition currently treated [7].

There are over 50 different causes of ARDS (see Table 1), with sepsis and pulmonary aspiration being the most common $[8,9]$. The pathophysiology of ARDS is complex, but its hallmarks include lung endothelial and alveolar epithelial injury with a consequent increase in membrane permeability and the accumulation of protein-rich debris in the alveolar air space [10]. Injury to the epithelium and endothelium is largely caused by a complex and exaggerated production of many inflammatory mediators (for exampleTNF- $\alpha$, IL-6) [8,11,12]. These host processes are likely responsible for the high rates of morbidity and mortality of this illness.

Supportive care strategies are the mainstay of therapy for ARDS. These include low tidal volume mechanical

Table 1 Examples of causes of acute lung injury in humans

\begin{tabular}{ll}
\hline Direct & Indirect \\
\hline Infectious pneumonia & Sepsis \\
Pulmonary contusion & Severe trauma \\
Aspiration & Surface burns \\
Smoke inhalation & Venous air embolism \\
Near drowning & Amniotic fluid embolism \\
Following upper airway obstruction & Neurogenic pulmonary \\
Acute eosinophilic pneumonia & edema \\
Bronchiolitis obliterans organizing & Multiple blood transfusions \\
pneumonia (BOOP) & Leukoagglutinin reactions \\
Miliary tuberculosis & \\
& Pancreatitis \\
& Drug reaction/overdose \\
& Cardiopulmonary bypass \\
& Multiple fractures \\
& Postbone marrow \\
transplantation
\end{tabular}

ventilation, restrictive fluid restriction strategies, and more recently prone positioning and paralysis [13-16]. Despite these interventions, the mortality for ARDS remains considerably high. Thus, the evaluation of novel therapeutics is required to reduce morbidity and death associated with this devastating syndrome [10]. Mesenchymal stromal cells (MSCs) may represent one novel therapy for this inflammatory condition.

MSCs (also known as 'adult stem cells', marrow stromal cells, or mesenchymal stem cells) have been well characterized and may be isolated from virtually every tissue type, including bone marrow, adipose tissue, and the umbilical cord [17]. In vivo,endogenous MSCs contribute to vascular homeostasis and respond to inflammation [18]. When cultured ex vivo and administered in larger numbers, MSCs are highly immunomodulatory [19]. In preclinical research, models described as 'acute lung injury' are used to study the clinical entity of ARDS. In these preclinical acute lung injury models, MSCs modulate the inflammatory response, augment tissue repair, enhance pathogen clearance, and reduce severity of injury, pulmonary dysfunction, and death [20-29].

As a prelude to a human clinical trial we will conduct a systematic synthesis of MSC therapy for preclinical acute lung injury. These data will help to determine whether there is a sufficient range of methodologically rigorous evidence to support a clinical trial administering MSCs in humans with ARDS. These data may also help to guide the objectives and designs of future preclinical and clinical research.

\section{Study question}

In controlled preclinical studies of acute lung injury, do MSCs reduce death and the severity of acute lung injury as described by the American Thoracic Society preclinical acute lung injury consensus conference [30], and do they enhance pathogen clearance in infectious acute lung injury models?

\section{Methods and design \\ Protocol and registration}

The systematic review and meta-analysis protocol was developed through discussions with our scientific research team of clinical (LM, DF) and preclinical research scientists (ML,SM, DS), an information specialist (BS), experts in knowledge synthesis and translation (DM, JG, MM, KS, MA), knowledge users from the Canadian Critical Care Trials Group (CCCTG; JM), the Canadian Stem Cell Network (MR), and the Canadian Council on Animal Care (CCAC; GG), and the Canadian Critical Care Translational Biology Group(CCCTBG; http://www.ccctbg.ca). It is listed on the Collaborative Approach to MetaAnalysis and Review of Animal Data from Experimental Studies (CAMARADES) website (http://www.camarades.info). 


\section{Study eligibility criteria}

We will include controlled comparative studies (randomized, quasi-randomized, and non-randomized) of preclinical acute lung injury that evaluate the efficacy and safety outcomes of MSC treatment.

\section{Preclinical model eligibility criteria}

We will include all preclinical in vivo animal models of experimentally induced acute lung injury that mimic at least some aspects of the pathophysiology of humans with ARDS according to the American Thoracic Society consensus criteria [30]. The inclusion of a wide range of acute lung injury animal models should enhance the generalizability of our study findings. Acute lung injury in animal models may be induced by several experimental methods (Table 2). These include direct(for example intratracheal bacteria or endotoxin), or indirect (for example intravenous or intraperitoneal bacteria or endotoxin) induction of infectious acute lung injury, and induction of injury by the ventilator (ventilator-induced lung injury), chemicals, or chemotherapeutic agents(for example bleomycin, oleic acid, hydrochloric acid), trauma, shock (for example hemorrhagic), or remote organ injury (for example pancreatitis, ischemia reperfusion). We will exclude neonatal animal models of acute lung injury since our proposed future clinical trial will focus on adults with ARDS and because the mechanisms of disease, and efficacy of treatments, are likely to be different in this group.

\section{Intervention}

The preclinical intervention group will include animals from studies that examine MSC celltypes (xenogeneic, syngeneic, or allogeneic cells from any tissue source). MSCs will be defined using minimal criteria set out in the International Society for Cellular Therapy (ISCT) consensus statement [31]. MSCs must be administered

Table 2 Examples of animal models of acute lung injury

\begin{tabular}{ll}
\hline Type of injury & Example of model \\
\hline Infection in lung & Intratracheal live bacteria \\
Bacterial components in lung & Intratracheal endotoxin \\
Systemic infection & Cecal ligation and puncture \\
Systemic bacterial components & Systemic endotoxin \\
Induction by ventilator & Ventilator-induced acute lung injury \\
Chemical or chemotherapeutic & Oleic acid \\
& Hydrochloric acid \\
Shock & Bleomycin \\
Trauma & Hemorrhagic \\
Remote organ injury & Chest trauma \\
& Ischemia reperfusion \\
\hline
\end{tabular}

during or following the induction of experimental acute lung injury. Experiments using pretreatment of MSCs will be excluded since they are clinically relevant for the prevention, but not the treatment, of human ARDS. In order to focus on non-manipulated MSCs, studies using either differentiated MSCs (for example MSCs that have been differentiated to an endothelial cell) or MSCs engineered to over- or under-express particular genes, or studies using a co-treatment with another therapy or cell type will be excluded.

\section{Comparison}

The preclinical comparison group will include animals from studies that have had experimental acute lung injury induced but have not been administered MSCs. This will allow us to perform effect size calculations in our meta-analysis to examine how efficacious and safe these cells are in the acute lung injury. We will use other control groups, such as healthy animals or sham-injured controls, to examine the severity of preclinical acute lung injury.

\section{Preclinical primary endpoint: death}

The primary endpoint is death, measured at specific time points after administration of the MSCs or control intervention. Time of death will be categorized as less than 2 days, between 2 to 4 days, and greater than 4 days. We will also measure all deaths that occur by the end of the follow-up period to give a measure of overall mortality. Death is a clinically meaningful endpoint given the high mortality rate of clinical ARDS [3]. The timing of our mortality assessments is intended to capture the burden of both early and late deaths as is typically seen in clinical trials of humans with acute lung injury (for example intensive care unit mortality, 28-day mortality, and 90-day mortality). The timing for these death assessments also reflects when the majority of deaths occur in the acute lung injury experimental animal setting. For example, one preclinical study demonstrated that mortality at 48 hours was $60 \%$, and the majority of deaths occurred between 30 to 40 hours post-experimental induction of acute lung injury [29].

\section{Preclinical secondary endpoints}

A consensus statement by the American Thoracic Society describes four key features that define acute lung injury in the animal model along with specific measurements to assess for the presence of each feature [30]. These are summarized in Table 3. Our secondary endpoints will include the four main features and focus on the 'very relevant' measurements defined by the consensus criteria [30]. These include histologic evidence of lung injury (for example lung injury score), alteration of the alveolar capillary barrier (for example increased concentration of high molecular weight 
Table 3 Features and measurements of acute lung injury in animal models

\begin{tabular}{|c|c|}
\hline Feature & 'Very relevant' measurements \\
\hline \multirow[t]{5}{*}{$\begin{array}{l}\text { Histological evidence of } \\
\text { tissue injury }\end{array}$} & $\begin{array}{l}\text { Accumulation of neutrophils in the alveolar } \\
\text { or the interstitial space }\end{array}$ \\
\hline & Formation of hyaline membranes \\
\hline & $\begin{array}{l}\text { Presence of proteinaceous debris in the } \\
\text { alveolar space (such as fibrin strands) }\end{array}$ \\
\hline & Thickening of the alveolar wall \\
\hline & $\begin{array}{l}\text { Enhanced injury as measured by a } \\
\text { standardized histology score }\end{array}$ \\
\hline \multirow[t]{5}{*}{$\begin{array}{l}\text { Alteration of the alveolar } \\
\text { capillary barrier }\end{array}$} & $\begin{array}{l}\text { An increase in extravascular lung } \\
\text { water content }\end{array}$ \\
\hline & $\begin{array}{l}\text { Accumulation of an exogenous protein or } \\
\text { tracer in the airspaces or the extravascular } \\
\text { compartment }\end{array}$ \\
\hline & $\begin{array}{l}\text { Increase in total bronchoalveolar lavage } \\
(\mathrm{BAL}) \text { protein concentration }\end{array}$ \\
\hline & $\begin{array}{l}\text { Increase in concentration of high molecular } \\
\text { weight proteins in BAL fluid (for example } \\
\text { albumin, IgM) }\end{array}$ \\
\hline & $\begin{array}{l}\text { Increase in the microvascular filtration } \\
\text { coefficient }\end{array}$ \\
\hline \multirow[t]{3}{*}{ Inflammatory response } & $\begin{array}{l}\text { Increase in the absolute number of } \\
\text { neutrophils in BAL fluid }\end{array}$ \\
\hline & $\begin{array}{l}\text { Increase in lung myeloperoxidase (MPO) } \\
\text { activity or protein concentration }\end{array}$ \\
\hline & $\begin{array}{l}\text { Increase in the concentrations of cytokines } \\
\text { in lung tissue or BAL fluid (IFN- } \gamma, \mathrm{TNF}-\mathrm{a}, \mathrm{IL}-6 \text {, } \\
\mathrm{IL}-1 \beta \text {, chemokine (C-X-C motif) ligand2, } \\
\text { chemokine (C-C motif) ligand 2, IL-8, IL-10, } \\
\text { prostaglandin E2, IL-1 receptor antagonist) }\end{array}$ \\
\hline \multirow[t]{2}{*}{ Physiological dysfunction } & Hypoxemia \\
\hline & Increased alveolar-oxygen difference \\
\hline
\end{tabular}

proteins in bronchoalveolar fluid), measures of the inflammatory response in the lung (for example pulmonary neutrophils, cytokines), and measures of physiological dysfunction (for example alveolar-arterial gradient of oxygen concentration). The American Thoracic Society consensus statement does not specify which lung inflammatory cytokines to measure. Hence, our team of translational cell and acute lung injury scientists (JM, SM, DS,ML) established consensus on what cytokines would be considered 'most relevant' for analysis in our systematic review (see Table 3).

Modified from the American Thoracic Society consensus statement [30]. This workshop was held with translational investigators to identify the defining features and measurements for acute lung injury animal models to simulate the pathophysiology of human ARDS. ARDS, acute respiratory distress syndrome; BAL, bronchoalveolar lavage; IFN, interferon; IgM, immunoglobulin M; IL, interleukin; MPO, myeloperoxidase; TNF, tumor necrosis factor.
For animal models that use infectious induction of acute lung injury, we will describe pathogen clearance (for example number of bacterial colony forming units) in different tissue beds, since animal sepsis models suggest that this is increased by MSCs [32-34].

All secondary endpoints will be analyzed in categories of time from the induction of acute lung injury of less than 6 hours, between 6 and 24 hours, between greater than 24 and 72 hours, and day 7 after the administration of MSCs versus controls. These time points for measurement were selected since the development of inflammation and acute lung injury occurs over time and contributes to death and morbidity in this population [2]. Where reported, the occurrence of adverse events will also be documented for each included study.

\section{Information sources}

Search strategies will be developed and tested through an iterative process by an experienced medical information specialist in consultation with the review team. Using the Ovid platform, we will search Ovid MEDLINE ${ }^{\bullet}$, Ovid MEDLINE ${ }^{\oplus}$ In-Process \& Other Non-Indexed Citations, and Embase Classic plus Embase. We will also search BIOSIS and Web of Science using Web of Knowledge. The strategy will be reviewed by another senior information specialist using the Peer Review of Electronic Search Strategies (PRESS) template [35].

Search strategies will use a combination of controlled vocabulary (for examplemesenchymal stem cells, acute lung injury, respiratory distress syndrome) and keywords (for example MSCs, ALI, acute/adult respiratory distress syndrome). Vocabulary and syntax will be adjusted across the databases. Two recently published animal filters [36,37], validated for PubMed/MEDLINE and Embase and amended slightly, will be used to increase relevancy. These filters will be adjusted for use in the other databases where a validated filter is unavailable. There will be no language or date restrictions on any of the searches. We will perform a grey literature search of selected conference websites not covered in the aforementioned databases, and will search the websites of animal research organizations. We will also search Mendeley and Google Scholar. The proposed Ovid search appears in Additional file 1.

The research team will contact authors of included studies to invite the further contribution of any unpublished data relevant to this review. The bibliographies of included studies and pertinent reviews will also be hand searched for further preclinical studies. Unpublished studies will be described in the results section but data from these studies will be included in any quantitative analyses. The research team will also contact biotechnology companies (for example Osiris Therapeutics, Columbia, MD, USA) that produce MSCs to identify further unpublished studies or studies that are currently ongoing. 


\section{Study selection}

The titles and abstracts of search results will be screened independently by two investigators. The fulltext of all potentially eligible studies will be retrieved and reviewed for eligibility, independently, by two members of the team using the a priori inclusion criteria described above. Disagreements between reviewers will be resolved by consensus or by a third member of the systematic review team (LM or ML). Reasons for exclusion of potentially eligible studies will be recorded to enable a transparent selection process and to be in accordance with the Preferred Reporting Items for Systematic Reviews and Meta-Analyses (PRISMA) guidelines developed for proper reporting of clinical systematic reviews [38].

\section{Data collection and process and data items}

Data will be extracted independently by two members of the research team into standardized, pilot-tested forms. Specific data elements are listed in Table 4.

\section{Assessment of risk of bias}

Risk of bias will be evaluated independently by two reviewers for each included preclinical study. Since no validated and standardized risk of bias checklist exists for preclinical studies, we will describe the biases of the included studies using the Cochrane risk of bias assessment tool [39]. Items in this tool include assessments for concealment of allocation, random sequence generation, blinding of personnel and the endpoint measurements, and completeness of endpoint reporting. Each bias criterion will be assigned a value of low, high, or unclear risk of bias for each included study [39].

\section{Assessment of construct validity and external validity}

We will also record features that will facilitate judgements of construct validity and external validity [40]. Construct validity in preclinical research concerns the extent to which an experimental system accurately models a clinical entity. These will include: type, age, gender, and strain of animal; presence of co-morbidities; type of acute lung injury model; timing, dose and mode of MSC administration; and use of co-interventions (for example fluid resuscitation, use of antibiotics for infectious acute lung injury models) (Table 5). External validity in preclinical research concerns the extent to which cause and effect relationships holdup under varied conditions [41]. In our study this will include the use of a multi-centre preclinical study (Table 5).

\section{Description of reporting}

We will describe the quality of reporting of the included preclinical studies using the elements of the Animal Research: Reporting of In Vivo Experiments (ARRIVE)
Table 4 Data collection elements

\begin{tabular}{|c|c|}
\hline Category & Specific items \\
\hline Study characteristics & $\begin{array}{l}\text { Study title, author, date of publication, } \\
\text { journal published, sponsorship, country } \\
\text { of publication }\end{array}$ \\
\hline $\begin{array}{l}\text { Study population } \\
\text { (animal model) }\end{array}$ & $\begin{array}{l}\text { Animal type, age, gender, strain, and } \\
\text { weight, presence of co-morbid illnesses }\end{array}$ \\
\hline $\begin{array}{l}\text { Type of acute lung } \\
\text { injury model }\end{array}$ & $\begin{array}{l}\text { Direct infection, indirect infection, } \\
\text { ventilator-induced injury, chemical- } \\
\text { induced injury, trauma, shock, pancrea- } \\
\text { titis, ischemia-reperfusion }\end{array}$ \\
\hline $\begin{array}{l}\text { Severity of experimentally } \\
\text { induced acute lung injury }\end{array}$ & According to the lung injury score [16] \\
\hline Intervention and comparison & $\begin{array}{l}\text { Time and route given, description of } \\
\text { preparation and suspension of MSCs and } \\
\text { controls }\end{array}$ \\
\hline Co-interventions & $\begin{array}{l}\text { Resuscitation fluids, antibiotics, and } \\
\text { mechanical ventilation }\end{array}$ \\
\hline Preclinical endpoints & $\begin{array}{l}\text { Death, features and measures of acute } \\
\text { lung injury (Table 3) that include: } \\
\text { histological evidence of pulmonary } \\
\text { injury;alteration in alveolar capillary } \\
\text { barrier;pulmonary and systemic } \\
\text { inflammatory response; measurements of } \\
\text { physiological dysfunction; and pathogen } \\
\text { clearance (measured using the number } \\
\text { of bacterial colony forming units in lung, } \\
\text { liver, spleen, and blood), and adverse } \\
\text { events }\end{array}$ \\
\hline Risk of bias assessments & $\begin{array}{l}\text { In accordance with the Cochrane risk of } \\
\text { bias tool, allocation concealment, } \\
\text { randomization, blinding (personnel, } \\
\text { endpoint measurements), and endpoint } \\
\text { measures (completeness of follow-up) }\end{array}$ \\
\hline $\begin{array}{l}\text { Quality of reporting of } \\
\text { individual preclinical studies }\end{array}$ & $\begin{array}{l}\text { In accordance with elements of the } \\
\text { ARRIVE guidelines [42] }\end{array}$ \\
\hline Other & $\begin{array}{l}\text { Industry sponsorship, single centre versus } \\
\text { multi-centre, and presence of a priori } \\
\text { sample size calculation. }\end{array}$ \\
\hline
\end{tabular}

ARRIVE, Animal Research: Reporting of In Vivo Experiments; MSC, mesenchymal stromal cell.

guidelines. The ARRIVE guidelines were developed to enhance the transparent and comprehensive reporting of research methods and results for in vivo animal experiments [42].

\section{Data analysis}

Where appropriate, dichotomous endpoints (for example death) from each included study will be pooled and described as odds ratios and 95\% confidence intervals incorporating a random effects modeling approach with the use of forest plots for presentation of the data [43]. Continuous endpoints will be pooled using the ratio of weighted means method with inverse variance random effects modeling [44]. Statistical heterogeneity of included preclinical studies will be measured using the $\mathrm{I}^{2}$ test with 95\% uncertainty intervals [45]. If there are sufficient number of studies $(\geq 10)$, an evaluation for the 


\begin{tabular}{|c|c|}
\hline Category & Specific items \\
\hline Death & $\begin{array}{l}\text { True death versus surrogate } \\
\text { endpoints }\end{array}$ \\
\hline Animal species & Mouse, rat, sheep, pig, other \\
\hline Strain & $\begin{array}{l}\text { Example for mice: BALB/c versus } \\
\text { C57Bl/6 }\end{array}$ \\
\hline Animal age & $\begin{array}{l}\text { Mature adult versus middle-aged } \\
\text { versus older adult for each species } \\
\text { (for example mouse } 3 \text { to } 10 \text { months, } \\
10 \text { to } 18 \text { months, } 18 \text { to } 24 \text { months) }\end{array}$ \\
\hline Gender & $\begin{array}{l}\text { Male versus female versus mix of } \\
\text { genders used }\end{array}$ \\
\hline Model of acute lung injury & See Table 2 \\
\hline Presence of co-morbidities & Yes versus no \\
\hline Severity of lung injury & Lung injury score \\
\hline MSC preparation & $\begin{array}{l}\text { Fresh versus fresh from previously } \\
\text { cryopreserved versus thawed } \\
\text { cryopreserved product }\end{array}$ \\
\hline $\begin{array}{l}\text { Timing of MSC administration } \\
\text { following induction of acute lung } \\
\text { injury }\end{array}$ & $\begin{array}{l}0 \text { to } 1 \text { hours versus } 1 \text { to } 6 \text { hours } \\
\text { versus }>6 \text { hours }\end{array}$ \\
\hline Route of MSC administration & $\begin{array}{l}\text { Intravenous versus intratracheal } \\
\text { versus intraperitoneal versus } \\
\text { intramuscular }\end{array}$ \\
\hline Type of control & $\begin{array}{l}\text { PBS versus normal saline versus } \\
\text { fibroblasts versus heat-killed MSCs }\end{array}$ \\
\hline Use of co-interventions & $\begin{array}{l}\text { Resuscitation fluids: yes versus no } \\
\text { Use of antibiotics in infectious } \\
\text { models: yes versus no }\end{array}$ \\
\hline Mechanical ventilation & Yes versus no \\
\hline $\begin{array}{l}\text { Number of participating study } \\
\text { centers }\end{array}$ & Single versus multi-center \\
\hline
\end{tabular}

MSC, mesenchymal stromal cell; PBS, phosphate buffered saline.

presence of publication bias will be conducted with funnel plot techniques, and Egger's regression test [46].

Sensitivity analyses to examine heterogeneity on the primary endpoint death will be carried out according to risk of bias assessments. Several subgroup analyses to examine preclinical heterogeneity will be conducted on the primary endpoint death (see Table 5). Where appropriate, analyses will include: definition of death; the type of animal model; animal age [47], gender, and strain; presence of co morbidities; type of experimental induction of acute lung injury (Table 2); severity of the acute lung injury model [30]; MSC preparation; timing of administration of MSCs from induction of acute lung injury; route of MSC administration; type of controls; use of co-interventions, antibiotics, and mechanical ventilation; single versus multi-centre study; and presence of an a priori sample size calculation. These subgroup analyses are exploratory and the results will be interpreted with caution.

\section{Knowledge translation}

The results of this systematic review will be of interest to a broad audience, and we have identified several knowledge users. We have planned an end of study knowledge translation workshop where our key findings will be disseminated to the group members and key stakeholders. In addition, this workshop will identify further avenues of dissemination and determine future research directions.

Our Principal Knowledge user (JM) will help facilitate presentation of study results at national and international critical care meetings. Two other knowledge users will aid the international dissemination of results through the Canadian Stem Cell Network, internationally through CellCAN (MR), and through the International Council for Laboratory Animal Science (ICLAS; GG) which encourages better reporting and translation of animal science.

\section{Discussion}

The results of this systematic review will inform translational and clinical scientists, clinicians, and health regulators internationally regarding the existing preclinical evidence for MSC therapy in acute lung injury. Our review is timely since there is an increasing amount of research dedicated to the evaluation or MSCs in many clinical domains [48]. Many therapeutics that appear promising in preclinical studies fail to translate into successful therapies. In a systematic review of highly cited animal studies, only one-third of studies translated to human randomized controlled trials (RCTs) [49]. This lack of translation may, in part, be related to failure to acknowledge the limitations of preclinical studies [50], as well as methodological flaws that bias the treatment effect in clinical trials that may also apply to preclinical studies. For example, preclinical interventional research in stroke and emergency medicine suggeststhat these weaknesses are associated with overestimates of the effect size for different treatments and publication bias [50,51]. Hence, our review is critical before spending the substantial energy and funding that is required to conduct a clinical trial. In a broader perspective, we also hope this review will identify challenges and barriers related to the conduct of these preclinical studies. Ultimately, our team will inform and enrich future preclinical and clinical MSC research that should aid the translation of this novel therapeutic in clinical trials.

\section{Additional file}

Additional file 1: Representative search strategy. Databases: Embase Classicplus Embase, 1947 to 5 June 2013; and Ovid MEDLINE In-Process \& Other Non-Indexed Citations and Ovid MEDLINE, 1946 to present.

\section{Abbreviations}

ARDS: Acute respiratory distress syndrome; ARRIVE: Animal Research: Reporting of In Vivo Experiments; BAL: Bronchoalveolar lavage; 
BOOP: Bronchiolitis obliterans organizing pneumonia;

CAMARADES: Collaborative Approach to Meta Analysis and Review of Animal Data from Experimental Studies; CCAC: Canadian Council on Animal Care; CCCTBG: Canadian Critical Care Translational Biology Group; CCCTG: Canadian Critical Care Trials Group; ICLAS: International Council for Laboratory Animal Science; IFN: Interferon; IgM: Immunoglobulin M; IL: Interleukin; ISCT: International Society for Cellular Therapy; MPO: Myeloperoxidase; MSC: Mesenchymal stromal cell; PBS: Phosphate buffered saline; PRESS: Peer Review of Electronic Search Strategies; PRISMA: Preferred Reporting Items for Systematic Reviews and Meta-Analyses; RCT: Randomized controlled trial; TNF: Tumor necrosis factor.

\section{Competing interests}

DS is President and CEO of Northern Therapeutics (Montréal, QC, Canada). SM is an employee of Northern Therapeutics. MM is a member of the UK Home Office Animals in Science Committee. The remaining authors have no competing interests to declare.

\section{Authors' contributions}

$L M, M L$, and $D M$ conceived the study design. $M L$ and $L M$ were responsible for initial drafting and manuscript revisions. $M L, J F$, and $L M$ were responsible for the data collection. JMG, AFT, KS, BS, MA, JM, GG, and DF provided critical revisions and statistical support. MM provided expertise in the design of preclinical systematic reviews. JM, DS, SM, and MR provided translational biology expertise, and provided oversight for planned eligibility criteria and outcome measures. JM, MR, and GG will oversee knowledge translation. All authors reviewed several drafts of the manuscript and approved the final version.

\section{Acknowledgements \\ This systematic review is funded by a Canadian Institutes of Health Research Knowledge Synthesis Grant (KRS9-126596). LM holds a Canadian Institutes of Health Research and Canadian Blood Services New Investigator Award. AFT holds a clinicalinvestigator award from the Fonds de la Recherche du Québec - Santé (FRQ-S).MA holds a Canadian Institutes of Health Research Postdoctoral Fellowship Award (Knowledge Translation Branch). JMG and MR hold Canada Research Chairs. DM holds a University of Ottawa Research Chair. MM acknowledges the support of the UK National Centre for the Replacement, Refinement and Reduction of Animals in Research (NC3Rs).The authors thank RisaShorr (Information Specialist, The Ottawa Hospital, Ottawa, ON, Canada) for providing assistance with the generation of a systematic search strategy, Marnie Gordon for administrative assistance, and the Canadian Critical Care Translational Biology Group for their guidance and critical review of the manuscript.}

\section{Author details}

${ }^{1}$ Department of Anesthesiology, University of Ottawa, Ottawa, ON, Canada. ${ }^{2}$ Department of Medicine (Division of Critical Care), University of Ottawa, Ottawa, ON, Canada. ${ }^{3}$ Regenerative Medicine Program, The Ottawa Hospital Research Institute, Ottawa, ON, Canada. ${ }^{4}$ Department of Cell and Molecular Medicine, University of Ottawa, Ottawa, ON, Canada. ${ }^{5}$ Clinical Epidemiology Program, The Ottawa Hospital Research Institute, Ottawa, ON, Canada. ${ }^{6}$ Department of Surgery (Critical Care), University of Toronto, Ottawa, ON, Canada. ${ }^{7}$ Department of Epidemiology and Community Medicine, University of Ottawa, Ottawa, ON, Canada. ${ }^{8}$ Division of Clinical Neurosciences, University of Edinburgh, Edinburgh, UK. 'Department of Medicine, University of Ottawa, Ottawa, ON, Canada. ${ }^{10}$ Canadian Council on Animal Care, Ottawa, ON, Canada. ${ }^{11}$ Population Health and Optimal Health Practices Unit (Trauma - Emergency - Critical Care Medicine), Centre de Recherche du CHU de Québec (Enfant-JésusHospital), Université Laval, Québec, QC, Canada. ${ }^{12}$ Division of Critical Care Medicine, Department of Anesthesiology, Université Laval, Québec, QC, Canada. ${ }^{13}$ Department of Medicine (Critical Care), Ottawa Hospital, Ottawa Hospital Research Institute, Centre for Transfusion and Critical Care Research, Canadian Blood Services, 501 Smyth Road, Box 201, Ottawa, ON K1H 8 L6, Canada. ${ }^{14}$ University of Ottawa, 451 Smyth Road, Ottawa, ON K1H 8 M5, Canada. ${ }^{15}$ Independent consultant, Ottawa, ON, Canada.

Received: 5 December 2013 Accepted: 4 April 2014

Published: 23 May 2014

\section{References}

1. Bernard GR, Artigas A, Brigham KL, Carlet J, Falke K, Hudson L, Lamy M, LeGall JR, Morris A, Spragg R: The American-European Consensus Conference on ARDS: definitions, mechanisms, relevant outcomes, and clinical trial coordination. Am J RespirCrit Care Med 1994, 149:818-824.

2. Definition Task Force ARDS, Ranieri VM, Rubenfeld GD, Thompson BT, Ferguson ND, Caldwell E, Fan E, Camporota L, Slutsky AS: Acute respiratory distress syndrome: the Berlin definition. JAMA 2012, 307:2526-2533.

3. Rubenfeld GD, Caldwell E, Peabody E, Weaver J, Martin DP, Neff M, Stern EJ, Hudson LD: Incidence and outcomes of acute lung injury. N Engl J Med 2005, 353:1685-1693.

4. Phua J, Badia JR, Adhikari NK, Friedrich JO, Fowler RA, Singh JM, Scales DC, Stather DR, Li A, Jones A, Gattas DJ, Hallett D, Tomlinson G, Stewart TE, Ferguson ND: Has mortality from acute respiratory distress syndrome decreased over time? A systematic review. Am J RespirCrit Care Med 2009, 179:220-227.

5. Herridge MS, Cheung AM, Tansey CM, Matte-Martyn A, Diaz-Granados N, A Saidi F, Cooper AB, Guest CB, Mazer CD, Mehta S, Stewart TE, Barr A, Cook D, Slutsky AS, Canadian Critical Care Trials Group: One-year outcomes in survivors of the acute respiratory distress syndrome. N Engl J Med 2003, 348:683-693.

6. Herridge MS, Tansey CM, Matte A, Tomlinson G, Diaz-Granados N, Cooper A, Guest CB, Mazer CD, Mehta S, Stewart TE, Kudlow P, Cook D, Slutsky AS, Cheung AM, Canadian Critical Care Trials Group: Functional disability 5 years after acute respiratory distress syndrome. N Engl J Med 2011, 364:1293-1304.

7. Canadian Institute for Health Information $(\mathrm{CIHI})$ : The Cost of Acute Care Hospital Stays by Medical Condition in Canada, 2004-2005. Ottawa, ON: ClHI; 2008.

8. Bhatia M, Moochhala S: Role of inflammatory mediators in the pathophysiology of acute respiratory distress syndrome. J Pathol 2004 202:145-156.

9. Hayes M, Curley G, Ansari B, Laffey JG: Clinical review: stem cell therapies for acute lung injury/acute respiratory distress syndrome - hope or hype? Crit Care 2012, 16:205.

10. Matthay MA, Ware LB, Zimmerman GA: The acute respiratory distress syndrome. J Clin Invest 2012, 122:2731-2740.

11. Goodman RB, Pugin J, Lee JS, Matthay MA: Cytokine-mediated inflammation in acute lung injury. Cytokine Growth Factor Rev 2003, 14:523-535

12. O'Grady NP, Preas HL, Pugin J, Fiuza C, Tropea M, Reda D, Banks SM, Suffredini AF: Local inflammatory responses following bronchial endotoxin instillation in humans. Am J RespirCrit Care Med 2001, 163:1591-1598.

13. Gotts JE, Matthay MA: Mesenchymal stem cells and acute lung injury. Crit Care Clin 2011, 27:719-733.

14. National Heart, Lung, and Blood Institute Acute Respiratory Distress Syndrome (ARDS) Clinical Trials Network, Wiedemann HP, Wheeler AP, Bernard GR, Thompson BT, Hayden D, De Boisblanc B, Connors AF Jr, Hite $\mathrm{RD}$, Harabin AL: Comparison of two fluid-management strategies in acute lung injury. N Engl J Med 2006, 354:2564-2575.

15. Papazian L, Forel JM, Gacouin A, Penot-Ragon C, Perrin G, Loundou A, Jaber S, Arnal JM, Perez D, Seghboyan JM, Constantin JM, Courant P, Lefrant JY, Guerin C, Prat G, Morange S, Roch A, ACURASYS Study Investigators: Neuromuscular blockers in early acute respiratory distress syndrome. $N$ Engl J Med 2010, 363:1107-1116.

16. Guerin C, Reignier J, Richard JC, Beuret P, Gacouin A, Boulain T, Mercier E, Badet M, Mercat A, Baudin O, Clavel M, Chatellier D, Jaber S, Rosselli S, Mancebo J, Sirodot M, Hilbert G, Bengler C, Richecoeur J, Gainnier M, Bayle F, Bourdin G, Leray V, Girard R, Baboi L, Ayzac L, PROSEVA Study Group: Prone positioning in severe acute respiratory distress syndrome. $N$ Engl J Med 2013, 368:2159-2168.

17. da Silva ML, Chagastelles PC, Nardi NB: Mesenchymal stem cells reside in virtually all post-natal organs and tissues. J Cell Sci 2006, 119:2204-2213.

18. Crisan M, Yap S, Casteilla L, Chen CW, Corselli M, Park TS, Andriolo G, Sun B, Zheng B, Zhang L, Norotte C, Teng PN, Traas J, Schugar R, Deasy BM, Badylak S, Buhring HJ, Giacobino JP, Lazzari L, Huard J, Peault B: A perivascular origin for mesenchymal stem cells in multiple human organs. Cell Stem Cell 2008, 3:301-313.

19. Crisostomo PR, Wang M, Markel TA, Lahm T, Abarbanell AM, Herrmann JL, Meldrum DR: Stem cell mechanisms and paracrine effects: potential in cardiac surgery. Shock 2007, 28:375-383. 
20. Islam MN, Sun L, Lindert J, Das SR, Bhattacharya J: Restoration of alveolar bioenergetics by bone marrow-derived mesenchymal stromal cells [abstract]. Am J RespirCrit Care Med 2011, doi:10.1164/ajrccm-conference.2011.183.1_Meeting Abstracts.A1245.

21. Wang $L, T u X H$, Zhao P, Song JX, Zou ZD: Protective effect of transplanted bone marrow-derived mesenchymal stem cells on pancreatitisassociated lung injury in rats. Mol Med Rep 2012, 6:287-292.

22. Tai WL, Dong ZX, Zhang DD, Wang DH: Therapeutic effect of intravenous bone marrow-derived mesenchymal stem cell transplantation on earlystage LPS-induced acute lung injury in mice. Nan Fang Yi Ke Da XueXue Bao 2012, 32:283-290.

23. Danchuk S, Ylostalo JH, Hossain F, Sorge R, Ramsey A, Bonvillain RW, Lasky JA, Bunnell BA, Welsh DA, Prockop DJ, Sullivan DE: Human multipotent stromal cells attenuate lipopolysaccharide-induced acute lung injury in mice via secretion of tumor necrosis factor-alpha-induced protein 6 . Stem Cell Res Ther 2011, 2:27.

24. Kim ES, Chang YS, Choi SJ, Kim JK, Yoo HS, Ahn SY, Sung DK, Kim SY, Park YR, Park WS: Intratracheal transplantation of human umbilical cord blood-derived mesenchymal stem cells attenuates Escherichia coliinduced acute lung injury in mice. Respir Res 2011, 12:108.

25. Yang H, Wen Y, Bin J, Hou-You Y, Yu-Tong W: Protection of bone marrow mesenchymal stem cells from acute lung injury induced by paraquat poisoning. ClinToxicol (Phila) 2011, 49:298-302

26. Manning E, Pham S, Li S, Vazquez-Padron Rl, Mathew J, Ruiz P, Salgar SK: Interleukin-10 delivery via mesenchymal stem cells: a novel gene therapy approach to prevent lung ischemia-reperfusion injury. Hum Gene Ther 2010, 21:713-727.

27. Krasnodembskaya A, Song Y, Fang X, Gupta N, Serikov V, Lee JW, Matthay MA: Antibacterial effect of human mesenchymal stem cells is mediated in part from secretion of the antimicrobial peptide LL-37. Stem Cells 2010, 28:2229-2238

28. Mei SH, McCarter SD, Deng Y, Parker CH, Liles WC, Stewart DJ: Prevention of LPS-induced acute lung injury in mice by mesenchymal stem cells overexpressing angiopoietin 1. PLoS Med 2007, 4:e269.

29. Gupta N, Su X, Popov B, Lee JW, Serikov V, Matthay MA: Intrapulmonary delivery of bone marrow-derived mesenchymal stem cells improves survival and attenuates endotoxin-induced acute lung injury in mice. J Immunol 2007, 179:1855-1863.

30. Matute-Bello G, Downey G, Moore BB, Groshong SD, Matthay MA, Slutsky AS, Kuebler WM, Acute Lung Injury in Animals Study Group: An official American Thoracic Society workshop report: features and measurements of experimental acute lung injury in animals. Am J Respir Cell MolBiol 2011, 44:725-738.

31. Dominici M, Le BK, Mueller I, Slaper-Cortenbach I, Marini F, Krause D, Deans R, Keating A, Prockop D, Horwitz E: Minimal criteria for defining multipotent mesenchymal stromal cells: the International Society for Cellular Therapy position statement. Cytotherapy 2006, 8:315-317.

32. Mei SH, Haitsma JJ, Dos Santos CC, Deng Y, Lai PF, Slutsky AS, Liles WC, Stewart DJ: Mesenchymal stem cells reduce inflammation while enhancing bacterial clearance and improving survival in sepsis. Am J RespirCrit Care Med 2010, 182:1047-1057.

33. Nemeth K, Leelahavanichkul A, Yuen PS, Mayer B, Parmelee A, Doi K, Robey PG, Leelahavanichkul K, Koller BH, Brown JM, Hu X, Jelinek I, Star RA, Mezey $\mathrm{E}$ : Bone marrow stromal cells attenuate sepsis via prostaglandin $\mathrm{E}(2)-$ dependent reprogramming of host macrophages to increase their interleukin-10 production. Nat Med 2009, 15:42-49.

34. Gonzalez-Rey E, Anderson P, Gonzalez MA, Rico L, Buscher D, Delgado M: Human adult stem cells derived from adipose tissue protect against experimental colitis and sepsis. Gut 2009, 58:929-939.

35. McGowan J, Sampson M, Lefebvre C: An evidence based checklist for the peer review of electronic search strategies (PRESS EBC). Evid Based Lib Inform Prac 2010, 5(1):149-154.

36. de Vries RB, Hooijmans CR, Tillema A, Leenaars M, Ritskes-Hoitinga M: A search filter for increasing the retrieval of animal studies in Embase. Lab Anim 2011, 45:268-270.

37. Hooijmans CR, Tillema A, Leenaars M, Ritskes-Hoitinga M: Enhancing search efficiency by means of a search filter for finding all studies on animal experimentation in PubMed. Lab Anim 2010, 44:170-175.

38. Moher D, Liberati A, Tetzlaff J, Altman DG: Preferred reporting items for systematic reviews and meta-analyses: the PRISMA statement. Ann Intern Med 2009, 151:264-269.
39. Higgins JP, Altman DG, Gotzsche PC, Juni P, Moher D, Oxman AD, Savovic J, Schulz KF, Weeks L, Sterne JA, Cochrane Bias Methods Group; Cochrane Statistical Methods Group: The Cochrane Collaboration's tool for assessing risk of bias in randomised trials. Br Med J 2011, 343:d5928.

40. Henderson VC, Kimmelman J, Fergusson D, Grimshaw JM, Hackam DG: Threats to validity in the design and conduct of preclinical efficacy studies: a systematic review of guidelines for in vivo animal experiments. PLoS Med 2013, 10:e1001489.

41. Kimmelman J, London AJ: Predicting harms and benefits in translational trials: ethics, evidence, and uncertainty. PLOS Med 2011, 8:e1001010.

42. Kilkenny C, Browne WJ, Cuthill IC, Emerson M, Altman DG: Improving bioscience research reporting: the ARRIVE guidelines for reporting animal research. Osteoarthritis Cartilage 2012, 20:256-260.

43. DerSimonian R, Laird N: Meta-analysis in clinical trials. Control Clin Trials 1986, 7:177-188

44. Friedrich JO, Adhikari NK, Beyene J: The ratio of means method as an alternative to mean differences for analyzing continuous outcome variables in meta-analysis: a simulation study. BMC Med Res Methodol 2008, 8:32.

45. Higgins JP, Thompson SG: Quantifying heterogeneity in a meta-analysis. Stat Med 2002, 21:1539-1558.

46. Hayashino $Y$, Noguchi $Y$, Fukui T: Systematic evaluation and comparison of statistical tests for publication bias. J Epidemiol 2005, 15:235-243.

47. Flurkey K, Currer JM, Harrison DE: Mouse models in aging research. In The Mouse in Biomedical Research: Immunology. Volume IV Immunology. 2nd edition. Edited by Fox JG, Barthold S, Davisson M, Newcomer CE, Quimby FW, Smith A. Burlington, MA: Academic; 2007:637-672.

48. Lalu MM, McIntrye L, Pugliese C, Stewart DJ: Safety of cell therapy with mesenchymal stromal cells (MSCs): a systematic review. Am J RespirCrit Care Med 2010, 181:A6043.

49. Hackam DG, Redelmeier DA: Translation of research evidence from animals to humans. JAMA 2006, 296:1731-1732.

50. van der Worp HB, Howells DW, Sena ES, Porritt MJ, Rewell S, O'Collins V, MacLeod RM: Can animal models of disease reliably inform human studies? PLoS Med 2010, 7:e1000245.

51. Sena ES, van der Worp HB, Bath PM, Howells DW, Macleod MR: Publication bias in reports of animal stroke studies leads to major overstatement of efficacy. PLoS Biol 2010, 8:e1000344

doi:10.1186/2046-4053-3-48

Cite this article as: Lalu et al:: Efficacy and safety of mesenchymal stromal cells in preclinical models of acute lung injury: a systematic review protocol. Systematic Reviews 2014 3:48.

\section{Submit your next manuscript to BioMed Central and take full advantage of:}

- Convenient online submission

- Thorough peer review

- No space constraints or color figure charges

- Immediate publication on acceptance

- Inclusion in PubMed, CAS, Scopus and Google Scholar

- Research which is freely available for redistribution

Submit your manuscript at www.biomedcentral.com/submit
C) BioMed Central 